\title{
Compliance with Environmental and Social Legislation in Certified Forestry Companies
}

\author{
Marcos Vinicius Santana Leite ${ }^{1}$, Andressa Francini Fonseca Antunes ${ }^{2}$, \\ Christian Dias Cabacinha ${ }^{3}$, Adriana Leandra Assis ${ }^{3}$, Aldenir Teixeira da Gama ${ }^{3}$, \\ Nilza de Lima Pereira Sales ${ }^{3}$ \\ ${ }^{1}$ Programa de Pós-graduação em Ciências Florestais, Universidade Estadual do Sudoeste da Bahia - UESB, Vitória da \\ Conquista/BA, Brazil \\ ${ }^{2}$ Programa de Pós-graduação em Engenharia Florestal, Universidade Federal de Lavras - UFLA, Lavras/MG, Brazil \\ ${ }^{3}$ Instituto de Ciências Agrárias, Universidade Federal de Minas Gerais - UFMG, Montes Claros/MG, Brazil
}

\begin{abstract}
The objective of this study was to evaluate the contribution of the FSC forestry certification system to improve the forestry sector, in terms of compliance to environmental and social laws and improvements in working conditions resulting from the certification process. Thirty-seven auditing reports from five Brazilian forestry companies were evaluated, throughout the 2006-2013 period. Non-compliance and observations were analyzed and organized into categories, which identified the main performance issues found in certified forestry organizations. 301 instances of non-compliance and 138 observations of audit reports were verified, where 48 and 57\% respectively, were linked to the two principles studied. For obtaining and/or maintaining the certificate it is necessary for all violations to be resolved. Therefore, it was concluded that forest certification contributes to the advancement of the forestry sector in Brazil, in relation to compliance with legal, social and labor issues.
\end{abstract}

Keywords: forestry certification, FSC, sustainability, forest management. 


\section{INTRODUCTION}

The forestry sector plays an important role in the conservation of Brazilian natural resources and in the quality of life of forest workers and rural communities, as described by Silva (2005). Despite the global financial crisis, the gross revenue of Brazilian forestry production increased by $4.6 \%$ in 2012 reaching $R \$ 56.3$ billion and employing approximately 4.4 million people (ABRAF, 2013). However, along with forestry production gains, concerns have grown regarding their environmental and social impacts (Basso et al., 2012).

According to Nardelli (2001), forest certification, is an alternative to the boycott campaigns against tropical forest products in the 90's. Thus, the interest in voluntary certification becomes a business strategy, mainly to access specific Market niches, where certification is required (Paiva, 2012). As demonstrated by Voivodic (2010), companies also seek certification to protect themselves from legal challenges, environmental organizations or social movements.

Leite (2007) points out that the 'green seal' is a kind of guarantee of origin to certify that wood (or other forestry inputs) used in a product come from forests managed in an ecologically sustainable, socially equitable and economically viable manner, in full compliance with the laws and regulations in effect. According to Busch (2008), forestry management certification brings countless benefits to several productive sectors, such as advances in mitigation of negative impacts of forestry operations on the environment for companies, adequate equipment, better working conditions for workers, and assistance in social issues for local communities through greater interaction between the company and local stakeholders.

Worldwide, considering the two main accrediting offices (FSC and PEFC), certified forest area has increased by $5.1 \%$ in 2012 , totaling 412.8 million hectares. In Brazil, in 2012, there was approximately 7.2 million hectares of FSC certified forests and 1.3 million hectares of PEFC certified forests, representing $2.1 \%$ of the whole global area (ABRAF, 2013). For Voivodic (2010), due to structural differences, the PEFC has greater presence in the private sector and the FSC has greater acceptance with civil society organizations.

Studies have already been carried out to verify the influence of forest certification in Brazil, such as
Spathelf et al. (2004) who analyzed its efficiency in natural forests conservation. Authors such as Castral (2003), Jacovine et al. (2006), Oliveira et al. (2011), Baptistel et al. (2011), Paiva (2012) and Paiva et al. (2015) have studied forest certification process in Brazilian forestry enterprises. Basso et al. (2012) studied the contribution of forest certification in forest companies in Minas Gerais State. However, there is still no evidence from the literature that demonstrates the benefits of forestry management certification FSC in different Brazilian forest companies as a whole. Additionally, it is known that forestry activity in Brazil, is mostly not realized in compliance with environmental, social and labor laws, due to several factors ranging from lack of control to high costs associated with meeting regulatory requirements. Thus, forest certification is as an option to reduce commonly faced problems, given that forestry companies must comply with the relevant laws, standards and requirements determined through certification in order to guarantee sustainable forest management practices and obtain certification. Therefore, it is very important to verify the results obtained via forestry certification in terms of compliance with environmental and social regulations, and improvements to working conditions in certified forestry companies throughout the country.

In this context, the purpose of this study was to evaluate the real contribution of the FSC forestry certification system to the improvement of the performance of the Brazilian forestry sector, in terms of compliance with legal regulations, improvements to working conditions and social impacts in the areas surrounding the forestry companies.

\section{MATERIAL AND METHODS}

The present study was based on an adaptation of the methodology used by Basso et al. (2012).

Social research methodologies characterized as descriptive according to Gil (2008) were applied, with the fundamental goals of describing the specific features (social, economic, among others) of a human population, or a phenomenon or relationships among variables. Some descriptive research goes beyond the simple identification of relations existing between variables, seeking to determine the origin and nature of these relations. 
This paper aimed to establish the relationship between the adherence of forestry companies to the certification process and compliance with current laws, focusing mainly on environmental and labor regulations. Research data was obtained via bibliographical and documentary research.

The database was composed through documentary research, which, according to Gil (2008), is very similar to bibliographical research, however the use of existing data comes from documentary sources which can be direct or second-hand documents. This study deals with the analysis of direct documents, which are documents that did not receive analytical treatment through official documentation, in this case, the reports that are available in public summary format audits.

These documents are made available for public consultation with the intention of increasing the transparency of the certification process. The reports describe all the initiatives realized by management to comply with the determined principles and criteria from the relevant regulations to obtain or maintain certification. The audit reports were downloaded from the FSC database, through the website (http://info.fsc. org/index) that contains all the public audit reports for certified forestry management units, or forest units with expired or suspended certificates.

37 annual audit reports for certification, maintenance or recertification from five forest companies with the FSC forest management certificate were analyzed. These enterprises cultivated mainly forests planted with exotic species. The five certified forest management units studied are distributed throughout the country, sampling one forestry company in each Brazilian geographical region: North, Northeast, Central-West, Southeast and South. These units totaled an area of 600.858 hectares, distributed as follows: $29.604,216.687$, $30.791,282.970,40.806$ hectares of forest enterprises labeled A, B, C, D and E, respectively. All forestry organizations studied were certified by FSC from 2006 to 2013, except for the forestry organization C, which only received certification from 2009 onward, being the only company in the Central-West that has developed this type of initiative during the study period. Despite the selection of companies having been made by region, the results are not presented considering each region separately. This criterion was adopted only in order to sample the impact of forest certification throughout the country. Moreover, today in Brazil, most of the certified enterprises in forestry management that farm exotic species for various purposes, are in the south and southeast, but in the last decade this scenario has begun to change with the advance of forestry companies to other regions such as the Northeast and Central-West.

The auditing process verifies the compliance of the management unit with the regulatory requirements. When there is non-performance or non-compliance with established standards, a non-compliance is applied to the company and a corrective measure is required. Non-compliance is the term used to indicate an instance of partial or complete non-fulfillment of a specific requirement of the standard. The identified non-compliance is also classified according to its gravity, as major or minor non-compliance.

Remarks can also be identified during audits especially regarding issues or early stages of a problem that is not non-compliance in itself, but is considered by auditors to be a non-compliance risk factor if no further action is taken by management. A remark can be a warning sign regarding a particular issue that if not handled can lead to non-compliance in the future.

All non-compliance and remarks for all 10 FSC Principles in each evaluated report were quantified, however, the analysis focused on Principle 1, regarding "Compliance with laws and FSC principles" and Principle 4, regarding "Community relations and workers' rights". Subsequently, remarks and non-compliance in terms of evaluated principles were classified in accordance with pertinent legislation or specific criteria required by standards. This classification into categories allowed the development of this study about common performance issues in the forestry organizations evaluated.

In the analysis of Principle 1, it was investigated if "forestry management met all applicable legislation of the country, international treaties and agreements to which the country is signatory, and its compliance with all the Principles and Criteria of the FSC". This principle requires that activities respect all national and local laws, and administrative requirements, including labor, taxation, environmental and financial regulations, the payment of any applicable and legally prescribed charges, and protection against illegal exploitation, human settlements and any other non-authorized activities. The requirements regarding the fulfillment of FSC Principles have the primary goal of obtaining 
long-term compliance with forest resources management, through economic and socio-environmental viability.

Principle 4 verifies if "forestry management activities maintained our extended, over the long term, the economic and social well-being of forestry workers and local communities". This principle includes all those issues related to workers, including full compliance with labor laws and regulations of the country. It also verifies steps to improving work conditions, such as: preference for local workers, controls to reduce turnover, coaching, trade unions and follow up of complaints, among others. It also requires an evaluation of social impacts for workers and forestry activities for neighboring communities.

The descriptive analysis of the database was performed from frequency tables and histograms to help to interpret the data and identify the main problems of performance in the evaluated forestry organizations.

\section{RESULTS AND DISCUSSIONS}

\subsection{Non-conformities}

The analysis of audit and monitoring reports from the five forest management units showed 301 cases of non-compliance related to the 10 principles of FSC standards. $48 \%$ of this total was related to Principles 1 and 4 , the focus of this study (Table 1). Principle 4 presented the greater number of non-compliances, followed by Principles 6 and 8, which refer to Environmental Impacts and Monitoring and Evaluations respectively. Principles 6 and 8 essentially consider topics from the FSC standard, and do not affect compliance with current legislation, and are, therefore, not dealt with in this document.

The study performed by Basso et al. (2012), to assess the contribution of forest certification in seven Forest Management Enterprises located in Minas Gerais State, Brazil, from 1998 to 2009, found 266 non-compliance referring to 10 principles of the FSC Standard, and $45.8 \%$ of these non-compliance were related to Principles 1 and 4.

Cubbage et al. (2010) studied the impact of forestry certification in Argentina, analyzing public reports of audits of 13 FSC certified forestry managements and found 137 non-compliances (Corrective Action Requests CAR) during the period from 2000 to 2007, a much lower number compared to this study. The authors also report that there were fewer non-compliances with companies that received certification for their plantations than for those who received certification for natural forests.

During the audit process, non-compliances are classified as major or minor, based on the level of danger represented by the non- compliance.

Non-compliance is considered major if it results in a fundamental failure to meet the criterion objective. A minor non-compliance is an unusual, temporary or non-systematic non-compliance, which has limited effects and does not compromise compliance with the objective of the criterion and the company is able to implement the corrective measure by the stipulated deadline.

Table 1. Number and percentage of total cases of non-compliance, major and minor non-compliance found in the audit reports analyzed for each principle.

\begin{tabular}{|c|c|c|c|c|c|c|}
\hline Principle & $\mathbf{N}^{\circ}$ of $\mathbf{N C}$ & $\% \mathbf{N C}$ & NC- Major & $\%$ NC - Major & NC-Minor & $\% \mathbf{N C}$ - Minor \\
\hline 1 & 30 & $10 \%$ & 4 & $10 \%$ & 26 & $10 \%$ \\
\hline 2 & 6 & $2 \%$ & 0 & $0 \%$ & 6 & $2 \%$ \\
\hline 3 & 4 & $1 \%$ & 2 & $5 \%$ & 2 & $1 \%$ \\
\hline 4 & 114 & $38 \%$ & 16 & $38 \%$ & 98 & $38 \%$ \\
\hline 5 & 7 & $2 \%$ & 2 & $5 \%$ & 5 & $2 \%$ \\
\hline 6 & 51 & $17 \%$ & 4 & $10 \%$ & 47 & $18 \%$ \\
\hline 7 & 18 & $6 \%$ & 3 & $7 \%$ & 15 & $6 \%$ \\
\hline 8 & 40 & $13 \%$ & 6 & $13 \%$ & 34 & $13 \%$ \\
\hline 9 & 23 & $8 \%$ & 5 & $12 \%$ & 18 & $7 \%$ \\
\hline 10 & 8 & $3 \%$ & 0 & $0 \%$ & 8 & $3 \%$ \\
\hline Grand Total & 301 & $100 \%$ & 42 & $100 \%$ & 259 & $100 \%$ \\
\hline
\end{tabular}

Where: NC $=$ Non-Compliance. 
As shown in Table 1, from 301 non-compliance found, 42 were classified as major and 259 as minor, representing $14 \%$ and $86 \%$ of the total number, respectively. Principle 1 presented 4 major and 26 minor non-compliances. Principle 4 presented 16 major and 98 minor instances of non-compliance. Principles 1 and 4 represent $48 \%$ of total major and minor non-compliance, in this study.

Basso et al. (2012) found 35 major and 231 minor non-compliances from a total of 266 verified. In other words, major and minor non- compliances represented 13 and $87 \%$, respectively. Principles 1 and 4, represented $37.1 \%$ of major and $52.9 \%$ of minor non-compliances.

When major non-compliances are detected, they must be corrected before the certificate can be granted. If the company is already certified, the deadline to achieve full compliance is three months after the detection of a major non-compliance. In this case, a new evaluation is necessary to remove the identified non-compliance. Minor non-compliances are registered for continuous monitoring, and must be corrected within a specified timeframe for the maintenance of certification.

\subsubsection{Principle 1: compliance with legislation and FSC principles}

All non-compliances related to Principle 1, were analyzed and subsequently classified in six distinct categories according to the problem verified.

The main problems observed were related to non-compliance with environmental regulations, constituting $40 \%$ of all cases. Secondly, current legislation showed $23 \%$ and labor legislation showed $17 \%$ of non-compliance, which is the subject of this study. Following this, illegal actions, compliance with FSC Principles and Criteria and lawsuits and legal issues, with $10 \%, 7 \%$ and $3 \%$ of non-compliances, respectively, were observed as shown in Figure 1.

The main problems related to Principle 1 were linked to environmental legislation (40\%), focusing mainly on a lack of environmental permission for activities performed (gravel extraction, forest nurseries, wood charcoal production), annotation of legal reserves of properties, lack of water and high use license granting and monitoring for water use, presence of commercial plantations in areas of permanent preservation and use of oil burning for chain lubrication.

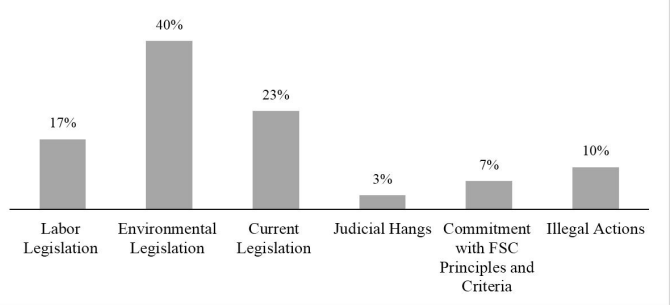

Figure 1. Percentage of non-compliance relating to Principle 1 classified the causes related to categories.

All non-compliance related to environmental regulations during the period covered by this study was resolved, showing the benefit of forestry certification in relation to legal compliance in activities realized by forestry companies.

Baptistel et al. (2011), analyzing the FSC forest certification process in companies in the state of Santa Catarina, Brazil, reports that in complying with environmental regulations, companies seeking forestry certification eliminated planting in inappropriate areas, registration of legal reserves and increased the suitability of planting areas. Therefore, they began to have a better understanding of their plantations, their dimensions and the real productivity, allowing for more efficient planning.

The problems associated with the current legislation (23\%) were mainly related to the breach of Article 99 of the Brazilian Traffic Code - Law n 9503/97 (Brasil, 1997) known as "The Law of Balance" involving trucks carrying wood driving overweight, as well as non-compliance with other laws applicable to forestry activities. All non-compliance related to these issues was also addressed during the review period for these certificates. For the main problems encountered in relation to overweight trucks, companies established methods to monitor and weigh the trucks, which have been effective, as seen in the audit reports.

Paiva (2012), analyzing forest certification in a pulp industry company in the state of Paraná, Brazil, showed in his study recurrent problems relating to the violation of the balance law. According to Lopes et al. (2006), these problems are intrinsic to forestry, since there are technological deficiencies involving ineffective or unreliable equipment used to meet the specifications contained in the legislation. 
The lower percentage of non-compliances related to labor legislation (17\%), can be justified considering that the FSC standard workers' rights and various aspects of applicable law are also addressed in Principle 4. Their main causes were related to incorrect payments to employees, implementation and compliance with the working hour regime, lack of monitoring of companies providing service for the implementation of labor legislation with its employees and non-compliance with clauses of the collective agreement. Forestry certification also contributes to compliance with labor laws as seen in reports, where all non-compliance was rectified over the period analyzed with better monitoring of workers' rights.

Castral (2003) studied the impact of forest certification on working conditions showing that the enforcement of labor legislation is being performed after implementation of forest certification in the company studied. There, workers met the established working schedule and when this was exceeded overtime was paid.

Several international studies have examined the effectiveness of FSC and PEFC forestry certification. For example in Europe, WWF analyzed 2817 Corrective Action Requests made by a series of World Wildlife Fund European Forest Programs in several countries, covering 18 million hectares of certified forests and concluded that FSC certification improved the conservation status, and levels of biodiversity were strengthened in forests. This included the consistent implementation of Environmental Impact Statements (EISs); identification, mapping and management or protection of natural areas and biotypes; increased deadwood levels; more natural regeneration to encourage species diversity; and restoration of threatened forest types. Better economic outcomes included more effective game management; better planning and long-term sustainability; more effective monitoring of objectives; improved marketing and product tracking; and improved recreational, cultural, and historical benefits. Social benefits included better implementation of health and safety legislation; better equipment training; and public safety improvements (WWF, 2005).

Illegal actions, commitments to FSC Principles and Criteria and legal disputes represent 10, 7, and 3\% respectively and are related to specific standard rules, not affecting legal compliance, so these will not be discussed in this study.

\subsubsection{Principle 4: community relations and workers law}

The same procedure was performed for cases of non-compliance related to Principle 4, however, these were grouped into three categories depending on their causes (Figure 2).

As shown in Figure 2 the main problems encountered were related to occupational health and safety, totaling $56 \%$, followed by workers' rights with $23 \%$ and impacts and social programs with $21 \%$.

In Argentina, most of the violations found were associated with improvements in the relationship with the community, with better communication and support for local communities and the rights of workers, mainly through training and safety. Following these, the second largest group was related to environmental impacts and protection of biodiversity. The tracking / monitoring and evaluation of activities was third (Cubbage et al., 2010).

As the item "Occupational Health and Safety" showed common violations in non-compliance analyzed in Principle 4, these violations were also classified according to the main causes of these problems and non-compliance will be better addressed in accordance with Figure 3.

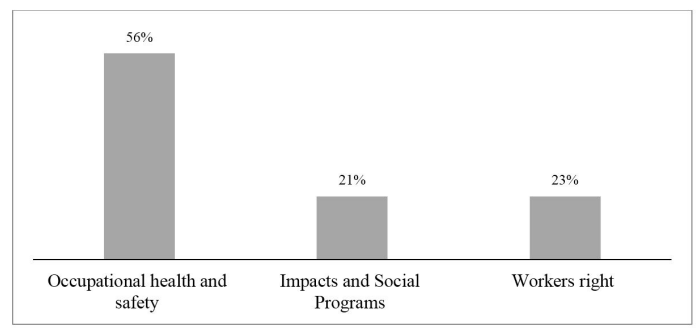

Figure 2. Percent of non-compliance related to Principle 4 classified according to the related causal categories.

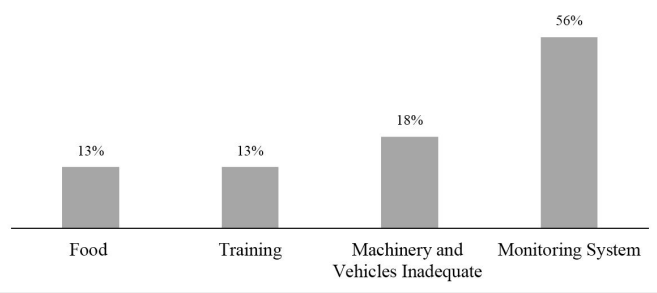

Figure 3. Percentage of non-compliance related to occupational health and safety, classified according to its main causes. 
Cases of non-compliance observed in terms of workers' rights (23\%) were mainly related to the lack or ineffective monitoring by forestry companies of service provider companies to ensure compliance with labor legislation, with evidence of working hours increased beyond permitted levels, employees working without registration and payment inconsistencies. For corrective actions, all companies intensified the monitoring of their service provider companies, with more intense and regular check ups involving hiring professionals specifically responsible for this monitoring. With compliance to labor regulations once again established forestry certification was reinstated, bringing benefits for the certified company and its employees.

Even given the workers' rights, problems with collective agreements were found where agreed benefits were not being fully met. There was a lack in terms of respect for employee rights and the guarantee of basic salary and benefits for all workers, including food stamps, health insurance, transportation vouchers, and payment of overtime, among others. All cases of non-compliance were resolved within the evaluated period contributing to the meeting of collective agreements, ensuring benefits for employees of certified operations.

Problems with dialogue and employee grievances were also found and a rapprochement between representatives of the company and staff was the solution created for this non-compliance.

Differences in treatment between service provider companies and its employees was also observed, which is not permitted according to forestry certification, ensuring that all workers who perform the same forestry activities have the same benefits and wages.

Castral (2003) reports that after analyzing forest certification there were no significant changes to worker salaries. However, the employee position becomes more stable with a fixed salary, independent of production, and the benefits guaranteed by the collective bargaining agreement.

The impacts and social programs representing $21 \%$ of non-compliance relating to Principle 4, are directly linked to the lack of evaluation of socioeconomic impacts on a scale and intensity proportional to the transactions, which includes all communities affected, as well as determining systematic measures for the prevention and mitigation for these impacts caused by forestry operations.
Another relevant factor was the relationship and communication of the forestry companies with the surrounding communities. When an enterprise opts for forestry certification it must have a channel to communicate with local communities and between stakeholders regarding critical issues requiring action and monitoring. To solve these problems proximity with surrounding communities with disclosure by the company was sought, establishing partnerships with Non-governmental Organization (NGOs) and trade unions, beneficial to both sides. For local communities, there is the development of the region, job creation, hand training work, financial or technical support and implementation of social projects, with the monitoring of performance and results achieved by the projects over time. As for the forestry companies, the greatest benefit is acceptance of the activities realized in the region, which is often a major hurdle to be faced. Therefore, this guarantees protection for the enterprise activity.

Baptistel et al. (2011) in his study found social improvements with the development of activities, programs, plans with communities, NGOs, associations, institutions and local schools. In this manner, it was possible to realize a more integrated production system with the surrounding community generating direct and indirect benefits. With this, the community becomes a partner in the surveillance and security of forest management units and generally showing the achievement of higher values.

Forest certification guarantees workers that their activities are conducted according to the standards established by law, according to NR 31- Occupational Health and Safety in Agriculture, Livestock, Forestry, Forest Use and Aquaculture. Thus, the monitoring of forestry systems developed by forestry companies showed the greatest non-compliance (56\%).

Monitoring systems made by forestry companies did not ensure that healthy, hygienic and safe working conditions for forestry workers were met. To remedy these problems companies expanded their monitoring of service provider companies and its own employees, carrying out prior inspections and verifying compliance with the requirements of NR 31, thus ensuring better working and service conditions in terms of current legislation.

Another requirement is that safety equipment must be adequate for the standard and should be made 
available and used in the workplace by employees. However, the monitoring of the use and supply of Personal Protection Equipment (PPE) was another very important factor found in the audit reports analyzed. This resulted in an intensification in the use and availability of PPE for their employees and service provider companies, ensuring greater safety and reducing the risks of accidents.

Paiva (2012) reports that the use of PPE is complicated by the worker awareness regarding the importance of its use, the non-compliance with operational requirements, and the underestimation of the dangers associated with forestry activities. Castral (2003) discusses an alternative to ensure the use of PPE by workers involving the application of a punishment for noncompliance, which generated positive changes in terms of the use of equipment.

The living quarters for workers must be adequate to current legislation (NR31), which was also identified as inadequate by the established monitoring systems. Surveys were extended to the accommodation of employees to remedy the non-compliance found during the study period. It notes that because of the difficulty to monitor and maintain these quarters, some companies chose to no longer use this system, bringing a greater benefit to workers living under these conditions.

The exposure of forestry workers to accidents and diseases caused by the activities performed was also identified by the study. Corrective measures required by forestry certification to mitigate accidents and illnesses that occur through exposure during work, include conducting admission tests for regular employees, drafting documents such as an Environmental Risk Prevention Program and Control Program Occupational Health and identifying the relevant risks for each activity. Consequently, methods have been put in place to minimize or mitigate these risks through the use of PPE, performing gymnastics, and improving ergonomic conditions, among others.

The use of machinery and vehicles inadequate to the working situation (18\%), are mainly related to machines without minimal safety equipment, in a poor state of repair, inadequate passenger transport vehicles and with chemicals improperly stored, thus causing risks for workers using such vehicles or machines. To solve these problems, measures such as regular monitoring, and exchange or retirement of vehicles and machines that did not present minimal conditions of use were adopted, thus offering better working conditions and safety for its employees.

Problems related to Food and Training accounted for $13 \%$ of all non-compliance related to occupational health and safety. The main violations found related to food were the breach of Resolution RDC no 216 of 15 September 2004 setting out best practice for Food Service, regarding the qualitative and quantitative aspects of the meals served to the workers. In addition to providing drinking water in the work fountains, it must be fit for human consumption (Brasil, 2004). In an effort to solve this problem adjustments according to $\mathrm{RDC} \mathrm{n}^{\circ} 216$ were made obligatory. Therefore, workers at certified enterprises have adequate food for the activities realized, bringing great benefits to workers.

Castral (2003) found that after forestry certification there were significant improvements regarding worker supply, where in addition to receiving monthly food stamps, workers received food during the work period and they took their meals in a suitable environment.

Certification requires a training program and training for all activities performed by employees and contractors who run the enterprise. The problems relating to training are mainly related to first aid training, and those newly hired without proper and /or ineffective training. These factors may impact worker safety and to solve the problem partnerships were signed with entities who realize training in a schedule to include all employees. This led to a reduction of occupational accidents and optimization of activities.

Principle 4 showed a higher frequency of non-compliance due to the great difficulty of monitoring compliance regarding health and safety questions of existing workers in the country, and the difficulty to raise awareness of forestry workers to comply with these questions. Forestry activities have undergone a positive change regarding labor issues, which until then, were carried out in precarious conditions and in violation of any applicable laws. Workers were required to expend significant energy to ensure effective improvements. Regarding social issues, the certification system evaluation method occurs via stakeholder public consultations and brings direct answers from the surrounding population, who can express their dissatisfaction regarding forestry activities, leading to the identification of deviations during audits, and the occurrence of non-compliance and observations to be addressed by the project looking for social improvements. 
Paiva (2012) found that the main non-compliances related to Principle 4 were primarily related to health and safety questions and social issues.

Still, the same author observed that lower levels of non-compliance were related to worker safety aspects, such as the absence or misuse of PPE, lack of training, and a lack of corporate policy for the termination of third parties, among other safety aspects. On the other hand, the most significant non-compliance issues related to social questions, where the enterprise had to consider its role in influencing communities, engagement and perception of interested parties as well as existing communication tools. Demands relating to social needs included more specific initiatives by the enterprise, such as establishing initial meetings for forestry operations, responding to demands and minimizing direct impacts on the community, such as those from truck traffic, which include noise and dust.

Studies conducted in the US show that the main violations found in FSC certified companies are listed, in order, as: Management Plans (operations required to make improvements), Monitoring, Inventory and Mapping. Prominent ecological issues were also related to a high number of violations, such as: operations requiring improvements in the thematic area Sensitive Sites and High Conservation Value Forests, and areas of Threatened and Endangered Species, and Woody Debris, Snags and Heritage Trees have also been identified. Conditions addressing social issues, such as Special Cultural Sites and Worker Safety, generally have the lowest number of violations, with no violations found in conditions for Worker Wages and Living Conditions (Newsom et al., 2006).

It has been found that certified operations in the US are required to improve ecological aspects more frequently than social ones, which confirms the hypothesis proposed by some observers that the standards of forest certification in Northern countries tend to focus more on ecological issues, while southern countries tend to focus on economic and social aspects (Ros-Tonen, 2004).

\subsection{Audit observations}

In analyzing the audit reports of certified forestry enterprises in Brazil there were many observations, particularly regarding principles 1 and 4, showing the importance of analyzing this data given that observations are violations or breaches of an item from the norm or standard of FSC that may in the future lead to non-compliance.

The audit reports considered the five forest management units analyzed in this study. 138 observations for the 10 principles of the FSC standard were identified. Of these $57 \%$ were related to principles 1 and 4 (Table 2). Principle 4 showed the highest number of observations, followed by Principles 6 and 1 .

The observations found relating to Principle 1 totaled $10 \%$ (Table 2), these were analyzed and then selected and grouped into five distinct categories according to the problem verified, similar to the procedure for noncompliance.

\subsubsection{Principle 1: compliance with laws and FSC principles}

The main problems found in the comments in relation to Principle 1, were related to breaches of current legislation totaling $57 \%$. This was followed by an absence of commitment to the principles and criteria of FSC totaling 29\%, while legal disputes accounted for $14 \%$ as shown in Figure 4.

Table 2. Number and percentage of observations found in audit reports analyzed for each principle.

\begin{tabular}{|ccc|}
\hline Principle & Number of observations & $\%$ \\
\hline 1 & 14 & $10 \%$ \\
\hline 2 & 2 & $1 \%$ \\
\hline 3 & 3 & $2 \%$ \\
\hline 4 & 65 & $47 \%$ \\
\hline 5 & 4 & $3 \%$ \\
\hline 6 & 23 & $17 \%$ \\
\hline 7 & 13 & $9 \%$ \\
\hline 8 & 7 & $5 \%$ \\
\hline 9 & 3 & $2 \%$ \\
\hline 10 & 4 & $3 \%$ \\
\hline Grand Total & 138 & $100 \%$ \\
\hline
\end{tabular}

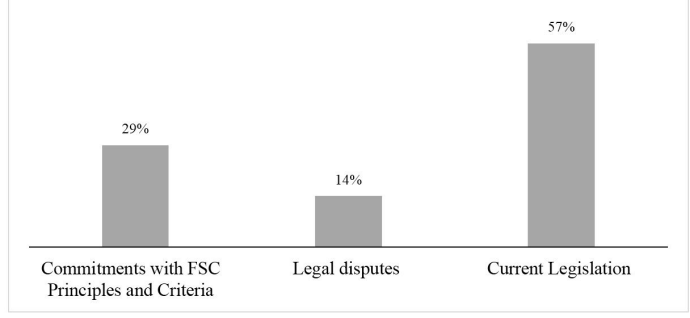

Figure 4. Percentage of observations relating to Principle 1 classified into categories related to their causes. 
The current legislation is that $57 \%$ is directly related to recommendations for frequent monitoring of state and local legislation so that there is non-compliance thereof, recommendations for implementation of a receiving system and analysis of the applicability of law. The lack of hygiene items and occupational health and safety in the operating fronts have also generated observations. Another factor was the need to obtain grants from the environmental agency and the implementation of procedures and monitoring systems for compliance with the Act scale. Thus observations relating to Principle 1, identified possible faults in the forestry companies to fulfill current legislation, at federal, state, and municipal levels and prevent these from becoming cases of non-compliance in the future.

The commitments to the principles and criteria of the FSC and legal disputes accounted for 29 and 14\%, respectively. They specifically targeted given standard rules, and did not affect legal compliance, so this was not considered in this study.

\subsubsection{Principle 4: community relations and workers' rights}

For Principle 4, the main problems encountered were related to health and safety totaling 55\%, workers' rights followed this with $28 \%$ and impacts and social programs had $17 \%$ according to Figure 5.

The main observations related to occupational health and safety (55\%) were related to failures in communication systems in emergency situations and the use of mobile phones for this purpose. This suggested existing facility improvements, hygiene and cleanliness of first aid equipment, improved signaling activities, inconsistencies in documents, use of PPE, machinery and vehicles with incomplete safety items, worker food monitoring, ergonomic issues and improvements

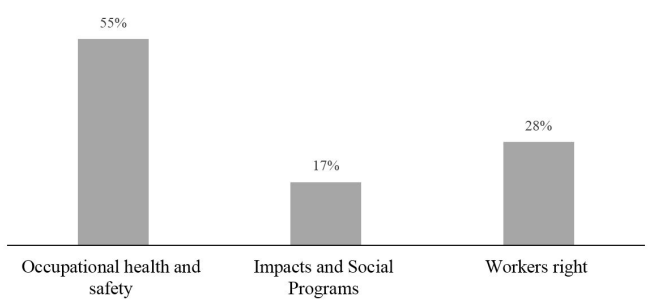

Figure 5. Percentage of observations relating to Principle 4 classified according to the related causal categories. to working conditions. Therefore, it is clear that observations are intended to promote improvements and prevent possible problems that can arise related to worker health and safety, helping the enterprise to monitor these factors and workers in the improvement of working conditions.

Observations classified as workers' rights (28\%) seek to minimize the differences in benefits offered to workers themselves and third parties, improving the benefits for all so that everyone is entitled to a health care plan, and prioritize the labor of workers from communities nearby to the forestry company. As previously observed, it was found that observations mark potential improvements for workers and highlight potential violations of labor rights.

The impacts and social programs (17\%) are directly linked to social projects developed by the company, and can be improved, expanded and better monitored for information of the benefits brought by the projects. Moreover, the best analysis of insertion of stakeholders into the communities shows benefits for the local communities with the development of social projects and increasing acceptance of the activities of the enterprise in the location.

Paiva (2012) in his study reports that Principle 4 showed the most significant violations in audit reports analyzed, including observations, and minor and major non-compliances, representing $41 \%$ of the total violations.

\section{CONCLUSION}

In the analysis of the FSC certification principles in relation to forestry management, the resolution of all violations identified during the study period showed that certification provided numerous benefits for the forestry sector and the locations situated around these projects. These benefits include better environmental control, compliance with labor laws and improvements in occupational health and safety conditions that contribute to the progress of these activities in Brazil.

\section{SUBMISSION STATUS}

Received: 16 mar., 2016

Accepted: 24 nov., 2016 


\section{CORRESPONDENCE TO}

Marcos Vinicius Santana Leite

Programa de Pós-graduação em Ciências

Florestais, Universidade Estadual do Sudoeste da

Bahia - UESB, Campus de Vitória da Conquista,

Estrada do Bem Querer, Km 04, Módulo de

Pós-graduação Stricto Sensu, $1^{\circ}$ andar, sala 04,

CP 95, CEP 45031-900, Vitória da Conquista, BA, Brazil

e-mail: santanav.marcos@gmail.com

\section{REFERENCES}

Associação Brasileira de Produtores de Florestas Plantadas - ABRAF. Anuário estatístico da ABRAF 2013: ano base 2012. Brasília: ABRAF; 2013. 142 p.

Baptistel AL, Canci RC, Langer M. Análise do processo de certificação florestal FSC em empresas florestais na região de Lages/SC. Unoesc \& Ciência 2011; 2(2): 111-118.

Basso VM, Jacovine LAG, Alves RR, Nardelli AMB. Contribuição da certificação florestal ao atendimento da legislação ambiental e social no Estado de Minas Gerais. Revista Árvore 2012; 36(4): 747-757. http://dx.doi.org/10.1590/ S0100-67622012000400016.

Brasil. Lei $n^{\circ}$ 9.503, de 23 de setembro de 1997. Institui o Código de Trânsito Brasileiro. Diário Oficial da República Federativa do Brasil, Brasília, DF (1997 set. 24).

Brasil. Resolução RDC no 216, de 15 de setembro de 2004. Dispõe sobre regulamento técnico de boas práticas para serviços de alimentação. Diário Oficial da República Federativa do Brasil, Brasília, DF (2004 set. 16).

Busch SE. Responsabilidade socioambiental de empresas fornecedoras de madeira certificada do tipo plantação [doctoral's thesis]. São Paulo: Programa de Pós-graduação em Saúde Pública, Universidade de São Paulo; 2008.

Castral AP. Impacto da certificação florestal nas condições de trabalho no complexo florestal [master's thesis]. São Carlos: Programa de Pós-graduação em Engenharia de Produção, Universidade Federal de São Carlos; 2003.

Cubbage F, Diaz D, Yapura P, Dube F. Impacts of forest management certification in Argentina and Chile. Forest Policy and Economics 2010; 12(7): 497-504. http://dx.doi. org/10.1016/j.forpol.2010.06.004.

Gil AC. Métodos e técnicas de pesquisa social. 6. ed. São Paulo: Atlas; 2008.

Jacovine LAG, Alves RR, Valverde SR, Silva ML, Nardelli AMB, Souza AP. Processo de implementação da certificação florestal nas empresas moveleiras nacionais. Revista Árvore
2006; 30(6): 961-968. http://dx.doi.org/10.1590/S010067622006000600011 .

Leite MCS. A importância da certificação florestal para o comércio exterior [specialization's thesis]. Cárceres: Programa de Pós-graduação em Gestão de Agronegócio, Universidade de Cuiabá; 2007.

Lopes ES, Cristo JFC, Pieper M. Avaliação técnica de um sistema de pesagem no carregamento florestal. Revista Árvore 2006; 30(4): 575-581. http://dx.doi.org/10.1590/ S0100-67622006000400010.

Nardelli AMB. Sistemas de certificação e visão de sustentabilidade no setor florestal brasileiro [doctoral's thesis]. Viçosa: Programa de Pós-graduação em Ciência Florestal, Universidade Federal de Viçosa; 2001.

Newsom D, Bahn V, Cashore B. Does forest certification matter? An analysis of operation-level changes required during the SmartWood certification process in the United States. Forest Policy and Economics 2006; 9(3): 197-208. http://dx.doi.org/10.1016/j.forpol.2005.06.007.

Oliveira LFS, Sais AC, Beli E. Implantação da certificação florestal em uma empresa do segmento papel e celulose. Engenharia Ambiental 2011; 8(4): 268-281.

Paiva SN, Silva DA, Oshiro CR, Hosokawa RT, Rochadelli R. A certificação florestal pelo FSC ${ }^{\oplus}$ : um estudo de caso. Floresta 2015; 45(2): 213-222. http://dx.doi.org/10.5380/ rf.v45i2.30055.

Paiva SN. Análise da certificação florestal FSC em uma empresa do segmento de celulose e papel no Estado do Paraná [doctoral's thesis]. Curitiba: Programa de Pós-graduação em Engenharia Florestal, Universidade Federal do Paraná; 2012.

Ros-Tonen MAF. Congress on globalisation, localisation and tropical forest management in the 21st century. Amsterdam: Amsterdam Research Institute for Metropolitan and International Development Studies; 2004. Final Report.

Silva LAGC. Certificação florestal. Brasília: Biblioteca Digital da Câmara dos Deputados; 2005.

Spathelf P, Mattos PP, Botosso PC. Certificação Florestal no Brasil: uma ferramenta eficaz para a conservação de florestas naturais? Floresta 2004; 34(3): 373-379. http:// dx.doi.org/10.5380/rf.v34i3.2423.

Voivodic MA. Os desafios da legitimidade em sistemas multissetoriais de governança: uma análise do Forest Stewardship Council [master's thesis]. São Paulo: Programa de Pós-graduação em Ciência Ambiental, Universidade de São Paulo; 2010.

World Wide Fund for Nature - WWF. The effects of FSC certification in Estonia, Germany, Latvia, Russia, Sweden and the UK: summary report \& country reports [online]. WWF; 2005. [cited 2015 May 4]. Available from: http://www. panda.org/about_wwf/what_we_do/forests/publications/ index $/ \mathrm{cfm}$ ? uNewsID $=18510$ 